\title{
The Dual Benefits Of Tax Credits: Taxpayer Income Generation And Economy Stimulus
}

Robin Guerrero, University of the Incarnate Word, USA

Theresa Tiggeman, University of the Incarnate Word, USA

Tracie Edmond, University of the Incarnate Word, USA

\begin{abstract}
Two important provisions of the Internal Revenue Code were the creation of the Earned Income Tax Credit and Child Tax Credit. Each of these credits were designed to reduce the amount of tax owed, thereby offsetting some of the increases in living expenses and federal income tax. For many this results in a smaller a tax liability. For others with little or no tax liabilities, the credit can result in a significantly increased refund. Many organizations such as the Volunteer Income Tax Income (VITA) Program, AARP and other similar organizations, cater to assisting these individuals. This is primarily due to the benefits that come from these credits which not only affect these individuals and their families but also the local economies. Larger refunds result in greater sustainability of taxpayer economic stability as well as an ongoing stimulation to the local economy. The purpose of this presentation is to describe the results of a study conducted involving the examination of each of these credits in relation to the taxpayer's Adjusted Gross Income (AGI). The goal of this study was to demonstrate the importance of these credits as to how they benefit the lower income taxpayers. The study examined various taxpayers who qualified for the credits over the course of the past three years. The results demonstrated that roughly $20 \%$ to $25 \%$ of these taxpayers' annual income is attributed to the assistance provided through these credits. Therefore, the need for the continuance of these credits is not only crucial for the welfare of the lower taxpayers but for stimulating the economy as well.
\end{abstract}

Keywords: Taxes, Earned Income Tax Credit, Child Tax Credit, Adjusted Gross Income

\section{INTRODUCTION}

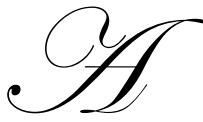

tax credit provides the taxpayer a dollar for dollar reduction in his or her tax liability. This is distinguished from a tax deduction which yields a reduction is tax liability based on the taxpayer's tax bracket percentage. For example, a taxpayer who is the $10 \%$ tax bracket will receive a $\$ 100$ tax benefit for a $\$ 1,000$ tax deduction. However, a $\$ 1,000$ tax credit will reduce the tax liability by the entire $\$ 1,000$ credit. Often a credit can be more valuable to a taxpayer than a deduction. Both the Earned Income Credit and the Child Tax Credit fall into the credit category and are not deductions.

A nonrefundable tax credit allows taxpayers to lower their tax liability to zero, but not below zero. Certain credits such as the Educational Credits function as nonrefundable credits. To illustrate, suppose a taxpayer had a tax liability of $\$ 500$. If the Education Credit that the taxpayer was eligible for was $\$ 800$, the benefit would only be $\$ 500$ because a nonrefundable credit is limited to the amount of tax liability of the taxpayer.

A refundable credit increases a refund over and above the federal withholding paid in by a taxpayer. Therefore, a refundable credit becomes a source of income for a taxpayer. For example, if a taxpayer has a refund due of $\$ 600$ and a refundable tax credit of $\$ 1,000$, he or she would receive $\$ 1,600$. For many taxpayers, as well as the local economy, these credits are an important resource. 
The credits in this study are both refundable and nonrefundable. Cornfield (2007) in his review of Ending Poverty in America: How to restore the American Dream, relates that the "poverty rate in the United States has changed little since the 1960s era of the Great Society and civil rights movement." Tax credits present a mitigation of poverty for the working poor.

Dickert-Conlin, Fitzpatrick and Hanson (2005) summarize the idea of refundable credits by noting that "for low-income individuals to utilize tax credits aimed at accomplishing social policy, they must be eligible for the credit. On the individual tax side, non-refundable tax credits will not reach the lowest-income individuals, who pay little or no federal income taxes."

\section{EARNED INCOME TAX CREDIT}

The Internal Revenue Service (2009) defines the Earned Income Tax Credit or the EITC as a refundable federal income tax credit for low to moderate income working individuals and families. Congress originally approved the tax credit legislation in 1975 in part to offset the burden of social security taxes and to provide an incentive to work. When the EITC exceeds the amount of taxes owed, it results in a tax refund to those who claim and qualify for the credit.

To qualify, taxpayers must meet certain requirements and file a tax return, even if they did not earn enough money to be obligated to file a tax return. The EITC has no effect on certain welfare benefits. In most cases, EITC payments will not be used to determine eligibility for Medicaid, Supplemental Security Income (SSI), food stamps, low-income housing or most Temporary Assistance for Needy Families (TANF) payments.

Forman (2004) relates that the EITC has been expanded and is now "one of the principal antipoverty programs in the federal budget. He further notes that this credit provides significant work stimulus for the working poor because a taxpayer must have earnings to obtain this income transfer.

According to the Internal Revenue Service (2009) The American Recovery and Reinvestment Act (ARRA) provides a temporary increase in the earned income tax credit (EITC) for taxpayers with three or more qualifying children. The maximum EITC for this new category is $\$ 5,657$. ARRA also increases the beginning point of the phase out range for the credit for all married couples filing a joint return, regardless of the number of children. These changes apply to 2009 and 2010 tax returns.

The EITC is a relatively small amount for the very low income taxpayers, and then it increases up to a certain earned income amount. After this amount is reached by a taxpayer, the EITC begins to decline until the phase out amount. The credit begins to phase out at $\$ 21,420$ for married taxpayers filing a joint return with children and completely phases out at $\$ 40,463$ for one child, $\$ 45,295$ for two children and $\$ 48,279$ for three or more children. For married taxpayers filing a joint return with no children, the credit begins to phase out at $\$ 12,470$ and completely phases out at $\$ 18,440$. This change increasing the amount, the income limits, and the number of children will infuse the local economy with new economic resources.

\section{CHILD TAX CREDIT}

This credit is for people who have a qualifying child or children under the age of 17 years. It is in addition to the earned income credit. The maximum amount you can claim for the credit is $\$ 1,000$ for each qualifying child. It begins as a nonrefundable credit. After the tax liability becomes zero due to the Child Tax Credit, the Additional Child Tax Credit comes into play. This credit is for certain individuals who get less than the full amount of the child tax credit. The additional child tax credit will give a taxpayer a refund even if he or she does not owe any tax. The Additional Child Tax Credit is a refundable credit.

According to the Internal Revenue Service (2009) under the American Recovery and Reinvestment Act (ARRA), more families will be eligible for the additional child tax credit because of a change to the way the credit is figured. Taxpayers who cannot take full advantage of the child tax credit because the credit is more than the taxes they owe may receive a payment for some or all of the credit not used to offset their taxes. 
ARRA reduces the minimum earned income amount used to calculate the additional child tax credit to $\$ 3,000$. Before ARRA, the minimum earned income amount was set to rise to $\$ 12,550$. Reducing the amount to $\$ 3,000$ permits more taxpayers to use the additional child tax credit and increases the amount of the payments they may receive. This change applies to tax years beginning in 2009 and 2010. The changes in this tax law will bring additional monies into the hands of the low income taxpayer and, in turn, into their economies

\section{METHODOLOGY}

\section{Purpose of Study}

The passing of the American Recovery and Reinvestment Act of 2009 has provided many new opportunities for the enrichment of the Child Tax and Earned Income credits. As a result of the adjustments to these credits, many taxpayers have expressed interest on the effects of the credits to their current tax situation which may be reflective of what is to come next filing season. The concern for the individuals is the significance of the credits to the refunds that they receive.

Therefore in order to examine the importance of the EIC and CTC, a sample study was conducted to determine the impact of these credits in relation to the taxpayer's total adjusted gross income. The goal of the study was to demonstrate how these credits represent a significant portion of the average annual income for these lower income taxpayers. More importantly, the purpose of our study was to demonstrate the significance of these credits to these individuals and their families.

\section{Sample/Participants}

In building a sample for this study, it was determined to target a particular group of taxpayers with a set of criteria. The first requirement was locating taxpayers with a filing status of "married filing a joint return" or "head of household" and at least one qualifying dependent child. The second requirement was locating taxpayers whose adjusted gross income was less than $\$ 28,000$ for each of the three years of study. These criteria were necessary to ensure that the taxpayer could potentially benefit from one or both of the tax credits. Based on the selection criteria, 47 taxpayers satisfied the requirements to participate in this study.

\section{Limitations of the Study}

Unfortunately, as with any research, there are certain limitations of this study. In this particular case, the first limitation of the study was the sample size of only 47 taxpayers. The sample size was limited because of the criteria chosen to be used to conduct this research. Therefore, the sample size may not be representative of the entire population. Finding qualifying individuals resulted in a small sample pull. Secondly, because of the uniqueness of this topic, prior research does not exist to compare this study to. As a result, all of the tests conducted, were original in format. Lastly, this study is limited to individuals that were previously existing clients of the researcher. The ability for a random sample was not available due to time constraints and availability.

\section{Collection and Examination of Data}

In order to conduct this research, the tax returns of each participant for the previous three years (20062008) were examined. For each of the years, data taken from these returns included the taxpayer's Adjusted Gross Income (AGI), the amounts of their Child Tax Credits (both regular and additional) and the amounts of their Earned Income Credit. AGI was used as opposed to gross income because of the necessary adjustments to income allowed for as a deduction by the IRS for such things as a one half deduction for self-employment tax, student loan interest payments and IRA contributions. The amount of the taxpayer's refund was not taken into consideration for this study because of varying differences in federal withholdings and estimated tax payments among taxpayers.

From this information, a three year average was created for each of these data categories. For the purposes of this study, regular and additional child tax credits were combined as one total. The averages for earned income credit and child tax credit were each compared to average adjusted gross income to determine their relation to income. The totals were reported as a percentage of income. 


\section{RESULTS}

The results of the study confirmed that individuals with an average adjusted gross income of $\$ 17,487$ generally have an average child tax credit of $\$ 636$ and receive and earned income credit of $\$ 3,386$. This is representative of $3.6 \%$ and $19.4 \%$ of AGI respectively. Therefore, these two credits account for more than $23 \%$ of low income taxpayer's annual gross earnings.

Naturally, because earned income credit is normally distributed based on income, as taxpayers made more, the amount this credit was reduced. In addition, taxpayers with little income may not have fully benefited from either of the child tax credits.

\section{DISCUSSION}

The Earned Income and Child Tax credits benefit millions of low income taxpayers each year. As demonstrated it can account for approximately $20 \%$ of their annual gross earnings. The ARRA of 2009 should bring about additional benefits for these taxpayers provided they still meet the qualifications for these credits.

Therefore, providing these credits for lower income taxpayers not only helps these individuals provide for their families but it also helps to stimulate the economy from this taxpayer segment. Therefore, the new changes to the tax law will not only benefit the families but it will help to stimulate the economy.

\section{REFERENCES}

1. ARRA and the additional child tax credit. (2009, March 27). Retrieved September 27, 2009, from Internal Revenue Service website: $\mathrm{http} / / / \mathrm{www}$. irs.gov/newsroom/article/0,,id=205670,00.html

2. ARRA and the earned income tax credit. (2009, March 27). Retrieved September 21, 2009, from Internal Revenue service website: $\mathrm{http}$ ://www.irs.gov/newsroom/article/0,,id=205666,00.html

3. Cornfield, D.(2009). Ending Poverty in America: How to Restore the American Dream. Review of medium_being_reviewed title_of_work_reviewed_in_italics. Social Forces, 87(4), 2203-2205. Retrieved September 27, 2009, from ProQuest Education Journals. (Document ID: 1847515331).

4. Dickert-Conlin, S., Fitzpatrick, K., \& Hanson, A. (2005, December). Utilization of Income Tax Credits by Low-Income Individuals. National Tax Journal, 58(4), 743-785. Retrieved September 27, 2009, from Business Source Complete database.

5. Foreman, J. B. (n.d.). Tax topics. In Earned income tax credit (tax policy center). Retrieved September 21, 2009, from Urban Institute Brookings Institution website: http://www.taxpolicycenter.org/taxtopics/encyclopedia/EITC.cfm .

6. It's easier than ever to find out if you qualify for EITC. (n.d.). Retrieved September 27, 2009, from Internal Reveue Service website: http://www.irs.gov/individuals/article/ 